\title{
Health Reform and Health Insurance Coverage of Early Retirees
}

Helen Levy, Thomas Buchmueller, and Sayeh Nikpay

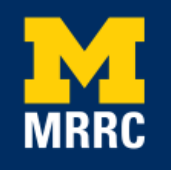

Project \#: UM16-15 


\title{
Health Reform and Health Insurance Coverage of Early Retirees
}

\author{
Helen Levy \\ University of Michigan \\ Thomas Buchmueller \\ University of Michigan \\ Sayeh Nikpay \\ Vanderbilt University
}

September 2016

\author{
Michigan Retirement Research Center \\ University of Michigan \\ P.O. Box 1248 \\ Ann Arbor, MI 48104 \\ www.mrrc.isr.umich.edu \\ (734) 615-0422
}

\section{Acknowledgements}

The research reported herein was performed pursuant to a grant from the U.S. Social Security Administration (SSA) funded as part of the Retirement Research Consortium through the University of Michigan Retirement Research Center Award RRC08098401. The opinions and conclusions expressed are solely those of the author(s) and do not represent the opinions or policy of SSA or any agency of the federal government. Neither the United States government nor any agency thereof, nor any of their employees, makes any warranty, express or implied, or assumes any legal liability or responsibility for the accuracy, completeness, or usefulness of the contents of this report. Reference herein to any specific commercial product, process, or service by trade name, trademark, manufacturer, or otherwise does not necessarily constitute or imply endorsement, recommendation or favoring by the United States government or any agency thereof.

\section{Regents of the University of Michigan}

Michael J. Behm, Grand Blanc; Mark J. Bernstein, Ann Arbor; Laurence B. Deitch, Bloomfield Hills; Shauna Ryder Diggs, Grosse Pointe; Denise Ilitch, Bingham Farms; Andrea Fischer Newman, Ann Arbor; Andrew C. Richner, Grosse Pointe Park; Katherine E. White, Ann Arbor; Mark S. Schlissel, ex officio 


\title{
Health Reform and Health Insurance Coverage of Early Retirees
}

\begin{abstract}
This paper presents evidence of the dynamics of health insurance coverage between 2008 and 2014 among early retirees, defined as individuals ages 55 to 64 who are not in the labor force. We focus on three questions. First, how did insurance coverage change among early retirees in 2014, when the new ACA options became available, compared with trends in coverage from 2008 to 2013? Second, are there differences between states that did and did not implement the ACA's Medicaid expansion in January 2014? Third, how did the income gradient in insurance coverage for early retirees change in 2014, both overall and in states with or without Medicaid expansion? We find that between 2013 and 2014, the fraction of early retirees without health insurance declined significantly from 14.7 percent to 11.2 percent, reversing a trend toward increasing uninsurance in recent years. This change was driven by increases in both Medicaid and private non-group coverage. Gains in coverage were larger in states that implemented the Affordable Care Act's Medicaid expansion in January 2014 than in states that did not. The gains in coverage disproportionately benefited low-income early retirees, and therefore reduced the gradient in coverage with respect to income. There is no evidence of an acceleration of the decline in employer-sponsored coverage for early retirees, either overall or in states that expanded Medicaid. These results suggest that the major coverage provisions of the ACA have increased coverage among early retirees, with particularly large gains among those with very low income in states that expanded Medicaid.
\end{abstract}

\section{Citation}

Levy, Helen, Thomas Buchmueller, and Sayeh Nikpay. 2016. "Health Reform and Health Insurance Coverage of Early Retirees.” Ann Arbor, MI. University of Michigan Retirement Research Center (MRRC) Working Paper, WP 2016-345.

http://www.mrrc.isr.umich.edu/publications/papers/pdf/wp345.pdf 


\section{Introduction}

A large spike in retirement occurs at age 62, when workers first become eligible to claim Social Security benefits; by age 64, more than half of all workers are retired (Gustman and Steinmeier, 2009). Medicare, however, does not become available for most of these workers until age 65. With employer-sponsored health insurance coverage for retirees declining rapidly (Buchmueller, Johnson, and LoSasso, 2006), early retirees are at risk of being uninsured. Beginning in 2014, the Affordable Care Act made new health insurance options available for individuals without access to employer-sponsored coverage, with subsidies for low- and middleincome households. Have early retirees embraced these new options?

This paper presents evidence of the dynamics of health insurance coverage between 2008 and 2014 among early retirees, defined as individuals ages 55 through 64 who are not in the labor force. We focus on three specific questions. First, how did sources of insurance coverage change among early retirees in 2014, when the new ACA options became available, compared with trends in coverage from 2008 to 2013? Second, are there systematic differences in coverage between early retirees in states that did and did not implement the ACA's Medicaid expansion in January 2014? Third, how did the income gradient in insurance coverage for early retirees change in 2014, both overall and in states with or without Medicaid expansion?

We begin by documenting that between 2008 and 2013, the percentage of early retirees without health insurance increased from 13.1 percent to 14.7 percent. This trend was driven by a decline in employer-sponsored insurance which fell from 48.2 percent to 40.7 percent over that period. Between 2013 and 2014, employer-sponsored coverage continued to decline, falling to 39.7 percent. However, the availability of new coverage options created by the ACA led to a reversal in the long-run decline in coverage. In 2014, the fraction of early retirees who were 
uninsured fell to 11.2 percent. This gain in coverage was attributable to a 3-percentage point increase in Medicaid coverage and a 1.6-percentage point increase in private, nongroup coverage among early retirees between 2013 and 2014.

Next, we focus on the 15 states that implemented the ACA's Medicaid expansion in January 2014 compared with the 23 that had not implemented expansion at all by the end of 2014. Comparing coverage dynamics among early retirees in these two groups of states, we see larger reductions in the fraction uninsured in Medicaid expansion states, driven by larger increases in Medicaid coverage. This difference was partially offset by slightly larger gains in private, nongroup coverage in nonexpansion states. There was no noticeable difference between the two groups of states in changes in employer-sponsored coverage, lending further support to the idea that the ACA coverage provisions did nothing to hasten the decline of this type of coverage.

Finally, we look at income gradients in early retirees’ probability of being uninsured. Throughout the period 2008 to 2014, about five percent of high-income early retirees - those with incomes exceeding four times the Federal Poverty Level (FPL) - were uninsured. Prior to 2014, between 21 and 24 percent of the lowest-income retirees were uninsured. In 2014, the fraction of the lowest-income early retirees who were uninsured dropped by approximately 9 percentage points in Medicaid expansion states and 4 percentage points in nonexpansion states, compared with 2013. As a result, the income gradient in uninsurance declined in both types of states, but it did so more in states that expanded Medicaid.

These results suggest that the major coverage provisions of the ACA have been effective at increasing health insurance among early retirees, with particularly large gains among those with very low income in states that have implemented Medicaid expansion. 


\section{Background}

\section{Background on early retiree health insurance}

Older adults have quite high rates of health insurance coverage compared with the rest of the nonelderly population; the probability of being uninsured peaks at age 26 and declines fairly smoothly throughout adulthood (Barnett and Vornovitsky, 2016: Figure 4). Nonetheless, the years approaching Medicare eligibility are a particularly risky time to lack coverage, both because older households are more likely to have a nest egg to protect (Boshara, Emmons, and Noeth, 2015) and because the risk of serious health problems increases with age. Employersponsored coverage for early retirees has long been declining (Buchmueller, Johnson, and LoSasso, 2006; Weller, Wenger, and Grould, 2006; Gould and Hertel-Fernandez, 2010). Swartz and Stevenson (2001) found that in 1999, 17.9 percent of 55 to 64 year olds who were not in the labor force had no insurance coverage. Levy (2007) estimated that 23 percent of individuals approaching retirement in the 1990s were uninsured at some point in the six years before they became eligible for Medicaid.

A large literature analyzes the effect of health insurance on the retirement decision. Nearly all of these papers find that the availability of insurance not contingent upon one's own continued work — from Medicare, as a dependent on a spouse's policy, from coverage intended for early retirees, or from COBRA — significantly increases the probability of retirement (Blau and Gilleskie, 2001, 2006; 2008; Fitzpatrick, 2014; French and Jones, 2011; Gruber and Madrian, 1995, 1996; Gustman and Steinmeier, 1994; Johnson, Davidoff, and Perese, 2003; Karoly and Rogowski, 1994; Leiserson, 2013; Lumsdaine, Stock, and Wise, 1996; Madrian and Beaulieu, 1998; Madrian, Burtless, and Gruber, 1994; Nyce, Schieber, Shoven, Slavov, and Wise, 2013; Robinson and Clark, 2010; Rogowski and Karoly, 2000; Rust and Phelan, 1997; Scholz and Seshadri, 2013; Shoven and Slavov, 2014; Strumpf, 2010). What many of these 
studies show is that individuals with a viable source of health insurance coverage in retirement for example, an offer of retiree coverage from one's own employer, or dependent coverage through a spouse's employer - are more likely to retire. Whether this can be considered hard evidence of a causal effect of insurance is debatable; it could also be viewed as evidence of strategic behavior on the part of older workers and would-be retirees, who make active decisions, sometimes at the household level, about how to get insurance. Hyde (2006) analyzes the health insurance transitions of married couples at the time of the husband's retirement. She finds that these couples largely manage to avoid being uninsured, but that this may involve buying highcost, private, nongroup coverage for wives when their husbands, who are typically slightly older, become eligible for Medicaid.

\section{Background on the ACA}

The Affordable Care Act included provisions to expand both private coverage and Medicaid that are intended to reach some of the 50 million individuals who were uninsured in 2010 when the law was enacted (DeNavas-Walt, Proctor, and Smith, 2011). The Medicaid expansions target very low-income adults without dependents, whom we refer to henceforth as “childless adults," although they may in fact have children who are not currently their dependents. Prior to the ACA, states covered low-income children and their families through Medicaid and the state Children's Health Insurance Program (CHIP). Most states did not provide coverage for childless, nonelderly adults, although a small number had done so (Kaiser Family Foundation, 2013). For example, Massachusetts implemented comprehensive reforms in 2007 that made subsidized insurance coverage available to all nonelderly adults with incomes below 300 percent of the poverty level (Long, 2008). The ACA allocated new federal funding for

all states to expand Medicaid to all nonelderly adults under 138 percent of the federal poverty level. Six states took advantage of an option in the law to begin expanding their Medicaid 
programs prior to 2014, although two of these limited their early expansions to shifting individuals already covered by a state-funded program into Medicaid (Sommers, Arntson, Kenney, and Epstein, 2013; Sommers, Kenney, and Epstein, 2014).

Although the ACA as enacted would have required the remaining states to expand their Medicaid programs in January 2014, a June 2012 Supreme Court ruling made the expansion optional. As a result, there is variation across states in when and whether they expanded Medicaid coverage for childless adults. Ten states and the District of Columbia had significantly expanded coverage for childless adults prior to 2014; this includes states that had raised the Medicaid eligibility threshold for childless adults to 100 percent of poverty or higher by 2011 (AZ, DC, DE, HI, NY, VT), states that had adopted other comprehensive reforms affecting childless adults (MA, WI), and states that increased coverage substantially through the ACA's Medicaid expansion prior to 2014 (CA, CT, MN). In some cases, these early expansions were phased in gradually. In the remaining states, 15 expanded coverage sharply in January 2014; two (MI and NH) expanded in April and August of 2014, respectively; five more (AK, IN, LA, MT, and PA) expanded in 2015 or the first half of 2016; and the remaining 18 had not implemented expansion as of July 2016. Table 1 summarizes state decisions about Medicaid expansion to date.

The law also implemented private insurance market reforms beginning in January 2014, such as prohibiting plans from denying coverage or increasing premiums based on an applicant's pre-existing condition. It established new health insurance marketplaces, sometimes called “exchanges," intended to facilitate individuals' plan choices by providing a website where enrollees can easily compare their plan options. Importantly, the law provides premium tax credits for families with income between 100 and 400 percent of poverty to purchase coverage through the marketplaces, provided that they do not already have access to Medicaid or coverage 
through an employer. The family's share of the premium is determined on a sliding scale and is capped at between 2 and 9.5 percent of family income. Premiums for marketplace plans cannot vary based on health status, and the law limits allowable variation based on age, so that older enrollees cannot be required to pay more than three times what a younger enrollee would be charged for the same plan.

These reforms, taken as a whole, dramatically expanded access to health insurance coverage for millions of Americans. Early studies have shown across-the-board increases in coverage and access to care, with larger increase in states that expanded Medicaid (Barnett and Vornovitsky, 2016; Cohen and Martinez, 2014; Frean, Gruber, and Sommers, 2016; Long et al., 2015, Sommers, Musco, Finegold et al., 2014; Wherry and Miller, 2016). No studies to date have focused on how the ACA's coverage provisions have affected early retirees.

Has the ACA increased retirement and, therefore, affected the composition of early retirees?

As noted above, some evidence suggests that the availability of alternatives to employersponsored health insurance makes workers more likely to retire. Moreover, the means-tested health insurance subsidies in the ACA, like any means-tested subsidies, reduce the incentive to supply labor (Mulligan, 2015). Both of these effects should, in theory, lead older workers to work less. Thus, we might expect to see a reduction in labor supply among older workers in all states as a result of the availability of marketplace coverage and premium tax credits, with an even larger reduction in states that also expanded their Medicaid programs; this may be one channel through which insurance coverage changes. However, several recent studies have found no change in labor supply in response to the ACA among the population as a whole (Kaestner et al. 2015; Gooptu et al., 2016; Leung and Mas, 2016) or among older individuals on the cusp of retirement (Levy, Buchmueller, and Nikpay, forthcoming; Gustman, Steinmeier, and Tabatabai, 2016). The lack of an effect on labor supply is consistent with the results of the Oregon Health 
Insurance Experiment (Baicker, Song, and Taubman, 2014), though it is at odds with studies of earlier Medicaid program changes in Wisconsin (Dague, DeLeire, and Leininger, 2014) and Tennessee (Garthwaite, Gross, and Notowidigdo, 2014). In any case, we ignore changes in labor supply and the possibility of changes in the composition of the early retiree population as a potential mechanism through which the source of coverage may change because the most relevant studies find no effect of the ACA on retirement behavior (Levy, Buchmueller, and Nikpay, forthcoming; Gustman, Steinmeier, and Tabatabai, 2016).

\section{Data}

The data for this study come from the Census Bureau's American Community Survey (ACS) for 2008 through 2014. The ACS began collecting information on health insurance in 2008, and 2014 is the most recent year of data currently available. The ACS offers several advantages for this study. The sample is very large, allowing us to analyze coverage dynamics for relatively small population subgroups, such as low-income early retirees. While the ACS offers a relatively short time series, the health insurance question has been consistent over time, unlike the Current Population Survey, which introduced new health insurance questions at the same time that the ACA reforms were implemented.

The ACS has one question about health insurance. Specifically, the ACS asks "Is this person CURRENTLY covered by any of the following types of health insurance or health coverage plans? Mark "Yes" or "No" for EACH type of coverage in items a - h." This is followed by a checklist of possible types of coverage:

a) Insurance through a current or former employer or union (of this person or another family member) 
b) Insurance purchased directly from an insurance company (by this person or another family member)

c) Medicare, for people 65 and older, or people with certain disabilities

d) Medicaid, Medical Assistance, or any kind of government-assistance plan for those with low incomes or a disability

e) TRICARE or other military health care

f) VA (including those who have ever used or enrolled for VA health care)

g) Indian Health Service

h) Any other type of health plan or health coverage plan

We define four insurance-related outcomes of interest: uninsured, which is defined as having none of the sources of coverage listed above; employer-sponsored coverage (option a above); private, nongroup coverage (option b above); and Medicaid or other public coverage (option d above). One limitation of the ACS is that we cannot further distinguish between, for example, private retiree health insurance from one's own former employer versus coverage as a dependent from the current employer-sponsored policy of a spouse.

In order to identify early retirees, we use the ACS employment status recode (ESR), which is available for all individuals 16 or older and takes on the following values:
a) Civilian employed, at work
b) Civilian employed, with a job but not at work
c) Unemployed
d) Armed forces, at work
e) Armed forces, with a job but not at work
f) Not in the labor force 
The ACS does not ask specifically about retirement. Therefore, we define early retirees as those who (1) are ages 55 through 64 at the time of the survey, and (2) are coded as "not in the labor force." While "not in the labor force" is not synonymous with retirement, it should be a good proxy in this age group. The ACS sample includes between 383,000 and 445,000 individuals who are ages 55 through 64 in each year between 2008 and 2014. In this age range, the fraction who are not in the labor force is 35 percent overall, increasing from 24 percent at age 55 to 55 percent at age 64 . As a result, once we restrict the sample to individuals ages 55 through 64 who are not in the labor force, we are left with a sample of approximately one million observations, or about 140,000 observations in each year.

We also stratify the sample by family income relative to poverty, using a variable provided by the Census Bureau on the ACS public use file (POVPIP). We create income categories using cutpoints that are relevant for ACA policies: 138 percent of poverty (the upperincome threshold for Medicaid eligibility in expansion states), 250 percent of poverty (the upperincome threshold for cost-sharing subsidies for nongroup policies purchased in the health insurance marketplaces), and 400 percent of poverty (the upper-income threshold for premium tax credits for nongroup policies purchased in the health insurance marketplaces). These three cutpoints divide the sample into four groups containing 29 percent (lowest income), 19 percent, 20 percent, and 32 percent (highest income) of early retirees.

\section{Analysis plan}

Our analysis begins by estimating trends in different sources of coverage - uninsured, Medicaid, private, nongroup, and employer-sponsored coverage - over time for the entire population of early retirees from 2008 to 2013. We test whether year-to-year changes in each type of coverage were statistically significant. Next, we compare these trends for two groups of 
early retirees: those living in either the 15 states that expanded Medicaid sharply in January 2014, which we label "expansion states"; and the 23 states that did not expanded Medicaid for childless adults at any time during 2014, which we label "nonexpansion states." Note that this latter groups includes five states that would subsequently implement Medicaid expansion, but had not done so as of 2014; see Table 1 for details. We estimate whether year-to-year changes in each type of coverage are statistically significant for each subgroup, as well as whether the changes differed across the two groups. Finally, we plot income gradients in the probability of not having insurance for each year from 2008 to 2014. For 2013 and 2014, we plot income gradients separately for expansion and nonexpansion states.

\section{Results}

National trends in sources of coverage for early retirees, 2008 to 2014

We begin with figures illustrating overall trends in coverage for early retirees. Figure 1 shows the fraction of early retirees reporting each type of coverage - uninsured, Medicaid, private, nongroup, and employer-sponsored - in each year from 2008 through 2014. Table 2 contains the data underlying Figure 1, as well as showing the year-to-year changes in the fraction with each type of coverage and the statistical significance of these changes. There were significant increases in both private nongroup coverage and Medicaid coverage between 2013 and 2014, resulting in a significant drop of 3.5 percentage points in the fraction uninsured. This reversed a consistent trend of small, significant increases in the fraction uninsured in every year between 2009 and 2013. The fraction of early retirees with employer coverage declined significantly in each year between 2008 and 2013 by about one or two percentage points; the 1.0 percentage point drop in employer coverage between 2013 and 2014 is no larger than any of the year-to-year changes observed prior to 2013. 
Comparison of states that did and did not expand Medicaid in January 2014

Next, we restrict our attention to the subset of 38 states that we define as expansion (15 states) or nonexpansion (23 states; see Table 1 for details). These states contain 69 percent of early retirees. Figure 2 is similar to Figure 1 but presents trends separately for expansion and nonexpansion states; the underlying data for Figure 2 are contained in Table 3. Several things are evident from a comparison of trends in the two types of states. First, the fraction uninsured had either increased or remained the same in each year in both groups of states since 2009-2010. The rate of uninsurance among early retirees was consistently higher in nonexpansion states by one or two percentage points; these differences were fairly stable, however, so that the trends in coverage prior to 2014 were quite similar for the two groups of states. In 2014, the fraction uninsured dropped significantly by 5.1 percentage points in expansion states and 2.5 percentage points in nonexpansion states. Both of these declines were significantly different from zero, and the decline in expansion states was significantly larger than the decline in nonexpansion states.

Second, these sharp declines in uninsurance were driven by significant increases in both Medicaid and private nongroup coverage. Medicaid coverage increased significantly in both groups of states, by 4.6 percentage points in expansion states and 1.4 percentage points in nonexpansion states. The 1.4 percentage point change in nonexpansion states is significantly more than zero, but significantly less than the gain in expansion states. This increase in Medicaid coverage in states that did not change their program eligibility rules may be due to a "welcome mat" effect, where previously eligible individuals signed up as a result of information or publicity surrounding the Affordable Care Act more generally and/or Medicaid expansion in other states. Private, nongroup coverage also increased significantly in both types of states, by 1.3 percentage points in expansion states and 2.0 percentage points in nonexpansion states. The 
gain in private, nongroup coverage in nonexpansion states of 2.0 percentage points was significantly larger, in the statistical sense, than the 1.3-percentage point gain in expansion states.

Third, while the rate of employer-sponsored coverage prior to 2014 was consistently lower by about four or five percentage points in nonexpansion states compared with expansion states, this difference was fairly stable, so that both types of states show the same downward trend in employer-sponsored coverage of one or two percentage points per year. This remains true for both groups between 2013 and 2014. The declines in employer coverage immediately following the implementation of the major ACA coverage provisions were slightly smaller than they had been in prior years, and did not differ significantly across the two groups of states.

Income gradients in uninsurance, 2008 to 2014

Figure 3 plots the fraction of early retirees who were uninsured in each year from 2008 through 2014, by income level. The income gradient in the probability of lacking coverage among early retirees was large and persistent, with little variation between 2008 and 2013. For the poorest group - those below 138 percent of poverty, or about $\$ 16,000$ for an individual in 2014 - the fraction without insurance was between 21 and 24 percent in each of these years. Among the highest-income early retirees - those with income above 400 percent of poverty, or about $\$ 47,000$ for an individual - only about 5 percent were uninsured prior to 2014 . In 2014 , the uninsurance rate for individuals in all income groups dropped significantly, with much larger declines in the lower income groups. In one year, the fraction of the poorest early retirees without insurance dropped from 22.9 percent to 17.5 percent. The fraction of the richest who were without coverage dropped from 5.7 percent to 4.3 percent. Thus, the disparity, whether measured in absolute or relative terms, dropped sharply in 2014, as is evident in Figure 3.

Because there was so little change in the income gradient between 2008 and 2013, we focus only on 2013 and 2014 in order to compare gradients for expansion and nonexpansion 
states. Figure 4 shows the income gradients in uninsurance for expansion and nonexpansion states in 2013 and 2014. We observe similar income gradients in coverage in 2013 in both groups of states; in 2014, we observe a striking flattening of the gradient in both groups, with more of an effect in expansion states. This is consistent with the fact that more than half of the lowest-income individuals in nonexpansion states had access neither to Medicaid nor to premium tax credits for exchange coverage. We calculate using the ACS data that in nonexpansion states, 31 percent of early retirees in the lowest income group have incomes above the poverty level and are therefore eligible for premium tax credits for marketplace coverage; the remaining 69 percent would be ineligible for premium tax credits.

\section{Discussion}

Our analysis finds that there were significant increases in both private and public insurance coverage among early retirees immediately following the implementation of the major coverage provisions of the ACA in January 2014. Coverage gains were larger in states that implemented the ACA's Medicaid expansion, although early retirees in nonexpansion states made up the difference to some extent with greater increases in private, nongroup coverage.

The erosion of health benefits for early retirees is well-documented. Our results suggest that the Affordable Care Act has helped to mitigate the consequences of this decline by making other sources of health insurance available to early retirees, without doing anything to hasten the further decline of employer coverage in the short run.

The implications of the ACA for early retirees' well-being likely go well beyond the coverage changes we document here. For example, we are not able to distinguish between private, nongroup coverage obtained directly from an insurance company outside of the ACA marketplace with no government subsidy and a marketplace policy that may be very heavily 
subsidized. To the extent that some individuals are switching from unsubsidized to subsidized coverage, this represents a large transfer of resources to those individuals without a measurable change (in the ACS) in their insurance coverage. Future research using other data sources could examine changes in early retirees' spending on health insurance premiums and out-of-pocket medical care, as well as nonmedical consumption, which may increase as the burden of health care spending is reduced.

Finally, the largest gains in terms of coverage were among the lowest-income early retirees. Should any of the 18 states that have, to date, not expanded Medicaid choose to do so, this would very likely further reduce the income gradient in uninsurance among early retirees. 


\section{References}

Baicker, K., Finkelstein, A., Song, J., and Taubman, S. (2014). The Impact of Medicaid on Labor Market Activity and Program Participation: Evidence from the Oregon Health Insurance Experiment. Am Econ Rev, 104(5), 322-328.

Barnett, Jessica C. and Marina S. Vornovitsky (2016). Current Population Reports, P60-257, Health Insurance Coverage in the United States: 2015, U.S. Government Printing Office, Washington, DC..

Blau, D. M., and Gilleskie, D. B. (2001). Retiree health insurance and the labor force behavior of older men in the 1990s. Review of Economics and Statistics, 83(1), 64-80.

Blau, D. M., and Gilleskie, D. B. (2006). Health insurance and retirement of married couples. Journal of Applied Econometrics, 21(7), 935-953.

Blau, D. M., and Gilleskie, D. B. (2008). The role of retiree health insurance in the employment behavior of older men. International Economic Review, 49(2), 475-514.

Boshara, R., Emmons, W., and Noeth, B. (2015). The Demographics of Wealth: How Age, Education and Race Separate Thrivers from Strugglers in Today’s Economy. Federal Reserve Bank of St. Louis.

Buchmueller, Thomas, Richard W Johnson, and Anthony T Lo Sasso. 2006. "Trends in retiree health insurance, 1997-2003." Health affairs no. 25 (6):1507-1516.

Cohen, Robin A., and Michael E. Martinez. 2014. Health Insurance Coverage: Early Release of Estimates from the National Health Interview Survey, January-March 2014. In National Health Interview Survey Early Release Program, edited by National Center for Health Statistics. Hyattsville, MD.

Dague, L., DeLeire, T., and Leininger, L. (2014). The Effect of Public Insurance Coverage for Childless Adults on Labor Supply: National Bureau of Economic Research. 
DeNavas-Walt, C., Proctor, B., and Smith, J. (2011). Income, poverty, and health insurance coverage in the United States: 2010, Current Population Reports, 2011, Series P60, No. 239.

Fitzpatrick, M. D. (2014). Retiree health insurance for public school employees: Does it affect retirement? Journal of Health Economics, 38, 88-98.

Frean, M., Gruber, J., and Sommers, B. D. (2016). Premium Subsidies, the Mandate, and Medicaid Expansion: Coverage Effects of the Affordable Care Act (No. w22213). National Bureau of Economic Research.

French, E., and Jones, J. B. (2011). The effects of health insurance and self-insurance on retirement behavior. Econometrica, 693-732.

Garthwaite, C., Gross, T., and Notowidigdo, M. J. (2014). Public Health Insurance, Labor Supply, and Employment Lock. The Quarterly Journal of Economics, 129(2), 653-696.

Gooptu, A., Moriya, A. S., Simon, K. I., and Sommers, B. D. (2016). Medicaid Expansion Did Not Result In Significant Employment Changes Or Job Reductions In 2014. Health Affairs, 35(1), 111-118.

Gould, Elise, and Alexander Hertel-Fernandez. "Early retiree and near-elderly health insurance in recession." Journal of aging and social policy 22, no. 2 (2010): 172-187.

Gruber, J., and Madrian, B. C. (1995). Health-Insurance Availability and the Retirement Decision. Am Econ Rev, 938-948.

Gruber, J., and Madrian, B. C. (1996). Health insurance and early retirement: evidence from the availability of continuation coverage Advances in the Economics of Aging (pp. 115-146): University of Chicago Press. 
Gustman, A. L., and Steinmeier, T. L. (1994). Employer-provided health insurance and retirement behavior. Industrial and Labor Relations Review, 48(1), 124-140.

Gustman, A. L., and Steinmeier, T. (2009). How changes in social security affect recent retirement trends. Research on Aging, 31(2), 261-290.

Gustman, A.L., Steinmeier, T.L., and Tabatabai, N. (2016). The Affordable Care Act as Retiree Health Insurance: Implications for Retirement and Social Security Claiming. Final report to the Michigan Retirement Research Center.

Hyde, J.S. (2006). Men With Health Insurance and the Women Who Love Them: The Effect of a Husband’s Retirement on His Wife’s Health Insurance Coverage. Michigan Retirement Research Paper UM06-15.

Johnson, R. W., Davidoff, A. J., and Perese, K. (2003). Health insurance costs and early retirement decisions. Industrial and Labor Relations Review, 56(4), 716-729.

Kaestner, R., Garrett, B., Gangopadhyaya, A., and Fleming, C. (2015). Effects of ACA Medicaid Expansions on Health Insurance Coverage and Labor Supply (No. w21836). National Bureau of Economic Research.

Kaiser Family Foundation (Producer). (2013, September 25, 2015). Medicaid: A Primer. Retrieved from www.kff.org

Karoly, L. A., and Rogowski, J. A. (1994). The effect of access to post-retirement health insurance on the decision to retire early. Industrial and Labor Relations Review, 48(1), 103-123.

Leiserson, G. (2013). Essays on the Economics of Public Sector Retirement Programs. (Ph.D.), Massachusetts Institute of Technology, Cambridge, MA. 
Leung, Pauline, and Mas, A. (2016). Employment Effects of the ACA Medicaid Expansions. National Bureau of Economic Research Working Paper 22540.

Levy, Helen, Thomas C. Buchmueller, and Sayeh Nikpay. “Health Reform and Retirement.” The Journals of Gerontology Series B: Psychological Sciences and Social Sciences (2016). doi: 10.1093/geronb/gbw115

Levy, Helen G. "Health Insurance Patterns Nearing Retirement.” Redefining Retirement: How Will Boomers Fare? (2007): 159-175

Long, S. K. (2008). On the road to universal coverage: impacts of reform in Massachusetts at one year. Health Affairs, 27(4), w270-w284.

Long, Sharon K. , Michael Karpman, Genevieve M. Kenney, Stephen Zuckerman, Douglas Wissoker, Adele Shartzer, Nathaniel Anderson, and Katherine Hempstead. 2015. Taking Stock: Gains in Health Insurance Coverage under the ACA as of March 2015. In Health Reform Monitoring Survey, edited by Urban Institute Health Policy Center. Washington, D.C.: Urban Institute.

Lumsdaine, R. L., Stock, J. H., and Wise, D. A. (1996). Why are retirement rates so high at age 65? Advances in the Economics of Aging (pp. 61-82): University of Chicago Press.

Madrian, B. C., and Beaulieu, N. (1998). Does Medicare Eligibility Affect Retirement? Inquiries in the Economics of Aging (pp. 109-131): University of Chicago Press.

Madrian, B. C., Burtless, G., and Gruber, J. (1994). The effect of health insurance on retirement. Brookings Papers on Economic Activity, 181-252.

Mulligan, C. B. (2015). Side Effects and Complications: The Economic Consequences of HealthCare Reform. University of Chicago Press. 
Nyce, S., Schieber, S. J., Shoven, J. B., Slavov, S. N., and Wise, D. A. (2013). Does retiree health insurance encourage early retirement? Journal of Public Economics, 104, 40-51.

Robinson, C., and Clark, R. (2010). Retiree health insurance and disengagement from a career job. Journal of Labor Research, 31(3), 247-262.

Rogowski, J., and Karoly, L. (2000). Health insurance and retirement behavior: evidence from the health and retirement survey. Journal of Health Economics, 19(4), 529-539.

Rust, J., and Phelan, C. (1997). How social security and medicare affect retirement behavior in a world of incomplete markets. Econometrica: Journal of the Econometric Society, 781831.

Schimmel, Jody (2006). "Men With Health Insurance and the Women Who Love Them: the Effect of a Husband's Retirement on His Wife's Health Insurance Coverage.” Michigan Retirement Research Center Research Paper No. WP 131 (2006).

Scholz, J. K., and Seshadri, A. (2013). Health Insurance and Retirement Decisions. Michigan Retirement Research Center Research Paper(2013-292).

Shoven, J. B., and Slavov, S. N. (2014). The role of retiree health insurance in the early retirement of public sector employees. Journal of Health Economics, 38, 99-108.

Smith, J. C., and Medalia, C. (2014). Health Insurance Coverage in the United States: 2013: US Department of Commerce, Economics and Statistics Administration, Bureau of the Census.

Sommers, B. D., Arntson, E., Kenney, G. M., and Epstein, A. M. (2013). Lessons from early Medicaid expansions under health reform: Interviews with Medicaid officials. Medicare and medicaid research review, 3(4). 
Sommers, B. D., Kenney, G. M., and Epstein, A. M. (2014). New evidence on the Affordable Care Act: coverage impacts of early Medicaid expansions. Health Affairs, 33(1), 78-87.

Sommers, B.D., Musco, T., Finegold, K., Gunja, M.Z., Burke, A., McDowell, A.M. (2014). “Health Reform and Changes in Health Insurance Coverage in 2014.” New England Journal of Medicine. 371(9):867-874.

Strumpf, E. (2010). Employer-sponsored health insurance for early retirees: impacts on retirement, health, and health care. International journal of health care finance and economics, 10(2), 105-147.

Swartz, Katherine, and Betsey Stevenson, "Health Insurance Coverage of People in the Ten Years before Medicare Eligibility,” in Ensuring Health and Income Security for an Aging Workforce, WE Upjohn Institute for Employment Research, 2001.

Weller, Christian E., Jeffrey B. Wenger, and Elise Gould. "A prescription for more retirement income security: Retiree health insurance coverage in an era of declining access to employer-sponsored insurance." Journal of aging and social policy 18.2 (2006): 11-30.

Wherry, L. R., and Miller, S. (2016). Early coverage, access, utilization, and health effects associated with the Affordable Care Act Medicaid expansions: A quasi-experimental study. Annals of internal medicine. 
Table 1: Timing of state Medicaid expansion for childless adults — How are states coded in our analysis of expansion versus nonexpansion states?

\begin{tabular}{|c|c|c|c|c|c|}
\hline & Category & States & $\begin{array}{l}\text { No. of } \\
\text { states }\end{array}$ & $\begin{array}{l}\text { \% of early } \\
\text { retirees }\end{array}$ & $\begin{array}{l}\text { Included in our analysis of } \\
\text { expansion/nonexpansion } \\
\text { states? }\end{array}$ \\
\hline (1) & $\begin{array}{l}\text { Early expanders } \\
\text { Expanded before 1/1/14 }\end{array}$ & $\begin{array}{l}\text { AZ CA CT DC DE } \\
\text { HI MA MN NY } \\
\text { VT WI }\end{array}$ & 11 & $24 \%$ & No \\
\hline (2) & $\begin{array}{l}\text { Expansion states } \\
\text { Expanded 1/1/14 }\end{array}$ & $\begin{array}{l}\text { AR CO IL IA KY } \\
\text { MD NV NJ }{ }^{\mathrm{a}} \mathrm{NM} \\
\mathrm{ND} \text { OH OR RI } \\
\mathrm{WA}^{\mathrm{a}} \mathrm{WV}\end{array}$ & 15 & $24 \%$ & $\begin{array}{l}\text { Yes, coded as expansion } \\
\text { states }\end{array}$ \\
\hline (3) & $\begin{array}{l}\text { Late expanders, group 1: } \\
\text { Expanded between } 2 / 1 / 14 \text { and } \\
\text { 12/31/14 }\end{array}$ & $\begin{array}{l}\text { MI (4/1/14) } \\
\text { NH (8/15/14) }\end{array}$ & 2 & $5 \%$ & No \\
\hline (4) & $\begin{array}{l}\text { Late expanders, group 2: } \\
\text { Expanded between 1/1/15 and 7/7/16 }\end{array}$ & $\begin{array}{l}\text { AK (9/1/15) } \\
\text { IN (2/1/15) } \\
\text { LA (7/1/16) } \\
\text { MT (1/1/16) } \\
\text { PA (1/1/15) }\end{array}$ & 5 & $9 \%$ & $\begin{array}{l}\text { Yes, coded as non- } \\
\text { expansion states }\end{array}$ \\
\hline (5) & No expansion as of $7 / 7 / 16$ & $\begin{array}{l}\text { AL FL GA ID KS } \\
\text { ME MS MO NE } \\
\text { NC OK SC SD TN } \\
\text { TX UT VA WY }\end{array}$ & 18 & $38 \%$ & $\begin{array}{l}\text { Yes, coded as non- } \\
\text { expansion states }\end{array}$ \\
\hline
\end{tabular}

Sources: Kaiser Family Foundation website: http://kff.org/health-reform/state-indicator/state-activity-around-expanding-medicaidunder-the-affordable-care-act/, downloaded Sept. 19, 2016; http://kff.org/medicaid/state-indicator/medicaid-income-eligibility-limitsfor-other-non-disabled-adults/, downloaded July 13, 2016; Sommers et al. (2014).

${ }^{a}$ Although New Jersey and Washington State also adopted early Medicaid expansion under the ACA, their early expansions were limited and involved primarily or exclusively shifting individuals who had previously been enrolled in state-financed programs onto Medicaid (Sommers et al. 2014). Full expansion of Medicaid eligibility to all individuals below 138 percent of poverty did not occur in these states until 2014. Therefore, we code them as having expanded Medicaid in January 2014. 
Table 2Trends in insurance coverage for early retirees Source: American Community Survey

\begin{tabular}{|c|c|c|}
\hline & $\mathrm{P}$ (uninsured) & $\Delta$ from last year \\
\hline 2008 & 0.131 & \\
\hline 2009 & 0.127 & -0.004 \\
\hline 2010 & 0.137 & 0.010 \\
\hline 2011 & 0.142 & 0.005 \\
\hline 2012 & 0.145 & 0.003 \\
\hline 2013 & 0.147 & 0.002 \\
\hline \multirow[t]{2}{*}{2014} & 0.112 & -0.035 \\
\hline & Medicaid & \\
\hline 2008 & 0.161 & \\
\hline 2009 & 0.200 & 0.039 \\
\hline 2010 & 0.205 & 0.005 \\
\hline 2011 & 0.211 & 0.006 \\
\hline 2012 & 0.220 & 0.009 \\
\hline 2013 & 0.226 & 0.006 \\
\hline \multirow[t]{2}{*}{2014} & 0.256 & 0.030 \\
\hline & Nongroup & \\
\hline 2008 & 0.168 & \\
\hline 2009 & 0.159 & -0.009 \\
\hline 2010 & 0.153 & -0.006 \\
\hline 2011 & 0.150 & -0.003 \\
\hline 2012 & 0.149 & -0.001 \\
\hline 2013 & 0.147 & -0.002 \\
\hline \multirow[t]{2}{*}{2014} & 0.163 & 0.016 \\
\hline & EHI & \\
\hline 2008 & 0.482 & \\
\hline 2009 & 0.466 & -0.016 \\
\hline 2010 & 0.450 & -0.016 \\
\hline 2011 & 0.436 & -0.014 \\
\hline 2012 & 0.424 & -0.012 \\
\hline 2013 & 0.407 & -0.017 \\
\hline 2014 & 0.397 & -0.010 \\
\hline Note: & & \\
\hline \multicolumn{3}{|c|}{$\begin{array}{l}\text { Changes that are significantly different from the } \\
\text { previous year with } p \leq 0.05 \text { are indicated in bold }\end{array}$} \\
\hline & & \\
\hline & & \\
\hline
\end{tabular}


Table 3

Trends in insurance for early retirees in Medicaid expansion and non-expansion states Source: American Community Survey

\begin{tabular}{|c|c|c|c|c|c|}
\hline & \multicolumn{2}{|c|}{ Non-expansion states } & \multicolumn{2}{|c|}{ Expansion states } & \\
\hline & $\mathrm{P}$ (uninsured) & $\Delta$ from last year & $\mathrm{P}$ (uninsured) & $\Delta$ from last year & \multirow{7}{*}{$\begin{array}{l}\text { Is 2013-2014 } \\
\text { change sig. different } \\
\text { for expansion vs. } \\
\text { non-expansion? }\end{array}$} \\
\hline 2008 & 0.143 & & 0.124 & & \\
\hline 2009 & 0.139 & -0.004 & 0.123 & -0.001 & \\
\hline 2010 & 0.151 & 0.012 & 0.130 & 0.007 & \\
\hline 2011 & 0.157 & 0.006 & 0.132 & 0.002 & \\
\hline 2012 & 0.160 & 0.003 & 0.136 & 0.004 & \\
\hline 2013 & 0.162 & 0.002 & 0.144 & 0.008 & \\
\hline \multirow[t]{2}{*}{2014} & 0.137 & -0.025 & 0.093 & -0.051 & Yes, $\mathrm{p}=0.000$ \\
\hline & P(Medicaid) & $\Delta$ from last year & P(Medicaid) & $\Delta$ from last year & \\
\hline 2008 & 0.151 & & 0.143 & & \\
\hline 2009 & 0.188 & 0.037 & 0.179 & 0.036 & \\
\hline 2010 & 0.193 & 0.005 & 0.182 & 0.003 & \\
\hline 2011 & 0.197 & 0.004 & 0.188 & 0.006 & \\
\hline 2012 & 0.208 & 0.011 & 0.198 & 0.010 & \\
\hline 2013 & 0.210 & 0.002 & 0.203 & 0.005 & \\
\hline \multirow[t]{2}{*}{2014} & 0.224 & 0.014 & 0.249 & 0.046 & YES, $p=0.000$ \\
\hline & \multicolumn{2}{|c|}{$\mathrm{P}$ (Nongroup) $\mathrm{I} \Delta$ from last year } & \multicolumn{2}{|c|}{$\mathrm{P}$ (Nongroup) $\mathrm{I} \Delta$ from last year } & \\
\hline 2008 & 0.17 & & 0.170 & & \\
\hline 2009 & 0.161 & -0.009 & 0.156 & -0.014 & \\
\hline 2010 & 0.154 & -0.007 & 0.153 & -0.003 & \\
\hline 2011 & 0.149 & -0.005 & 0.151 & -0.002 & \\
\hline 2012 & 0.149 & 0.000 & 0.150 & -0.001 & \\
\hline 2013 & 0.149 & 0.000 & 0.147 & -0.003 & \\
\hline \multirow[t]{2}{*}{2014} & 0.169 & 0.020 & 0.160 & 0.013 & YES, $p=0.037$ \\
\hline & P(Employer) & $\Delta$ from last year & P(Employer) & $\Delta$ from last year & \\
\hline 2008 & 0.459 & & 0.506 & & \\
\hline 2009 & 0.446 & -0.013 & 0.488 & -0.018 & \\
\hline 2010 & 0.422 & -0.024 & 0.472 & -0.016 & \\
\hline 2011 & 0.413 & -0.009 & 0.461 & -0.011 & \\
\hline 2012 & 0.398 & -0.015 & 0.449 & -0.012 & \\
\hline 2013 & 0.386 & -0.012 & 0.426 & -0.023 & \\
\hline \multirow[t]{4}{*}{2014} & 0.375 & -0.011 & 0.422 & -0.004 & $\mathrm{NO}, \mathrm{p}=0.176$ \\
\hline & Note: & & & & \\
\hline & Changes that ar & Ire significantly differ & from the & & \\
\hline & previous year $\mathrm{v}$ & with $\mathrm{p} \leq 0.05$ are indi & ted in bold & & \\
\hline
\end{tabular}




\section{Figure 1: Sources of insurance coverage for early retirees}

Source: American Community Survey, 2008 - 2014

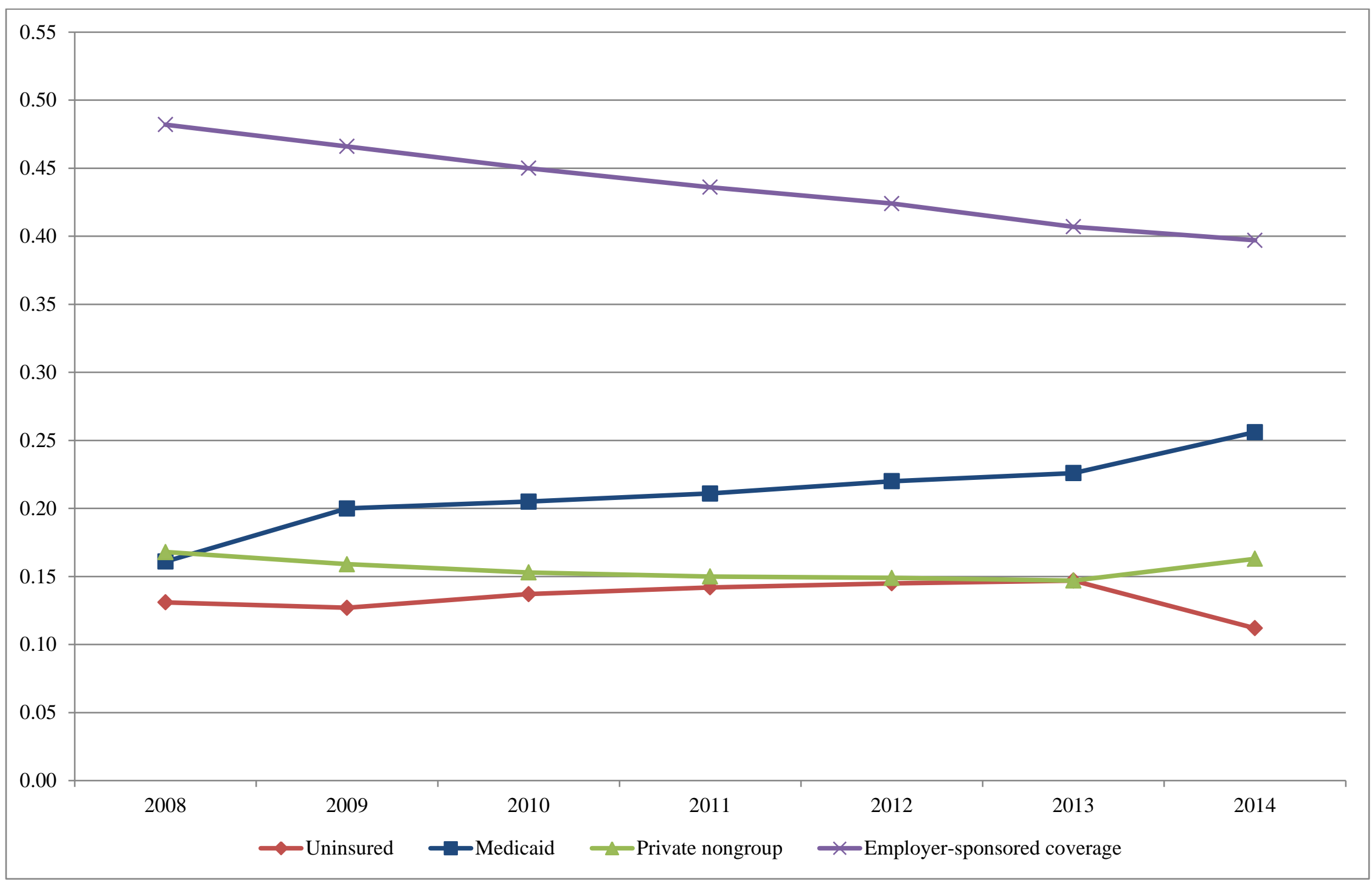


Figure 2: Sources of health insurance coverage for early retirees Medicaid expansion versus nonexpansion states

Source: American Community Survey

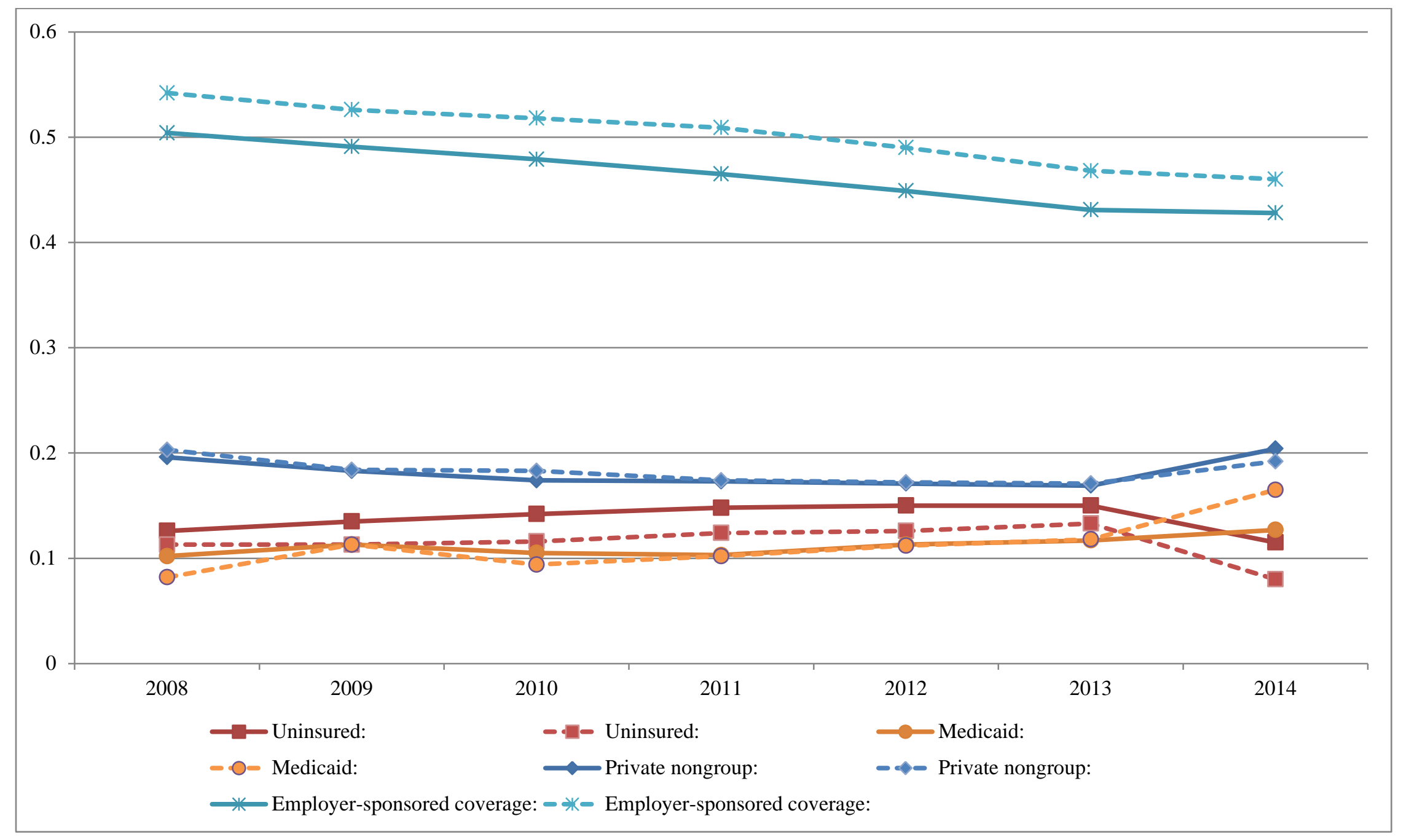


Figure 3: Fraction of early retirees uninsured by income level Source: American Community Survey

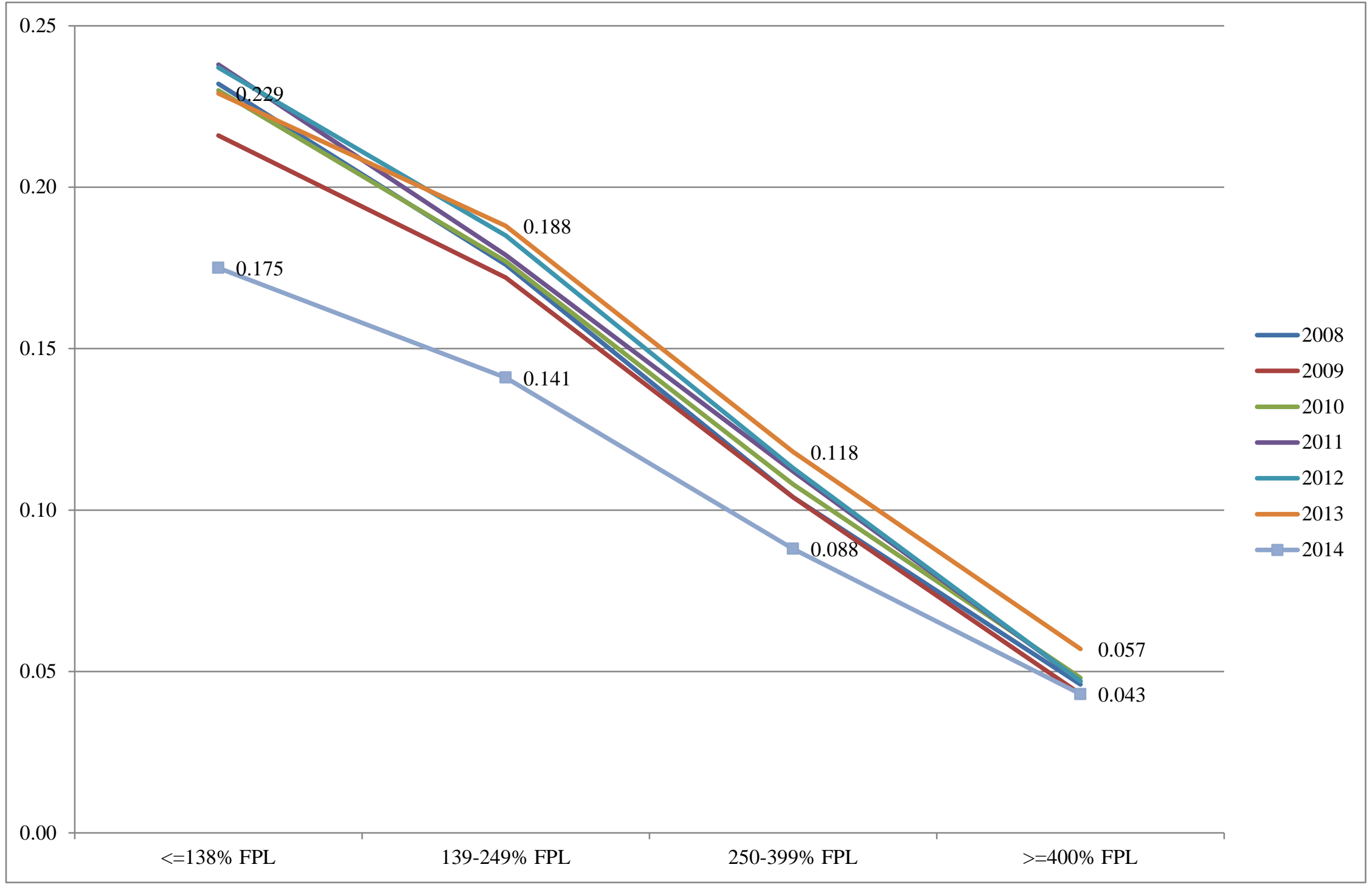


Figure 4: Fraction of early retirees uninsured by income level Medicaid expansion vs. nonexpansion states

Source: American Community Survey

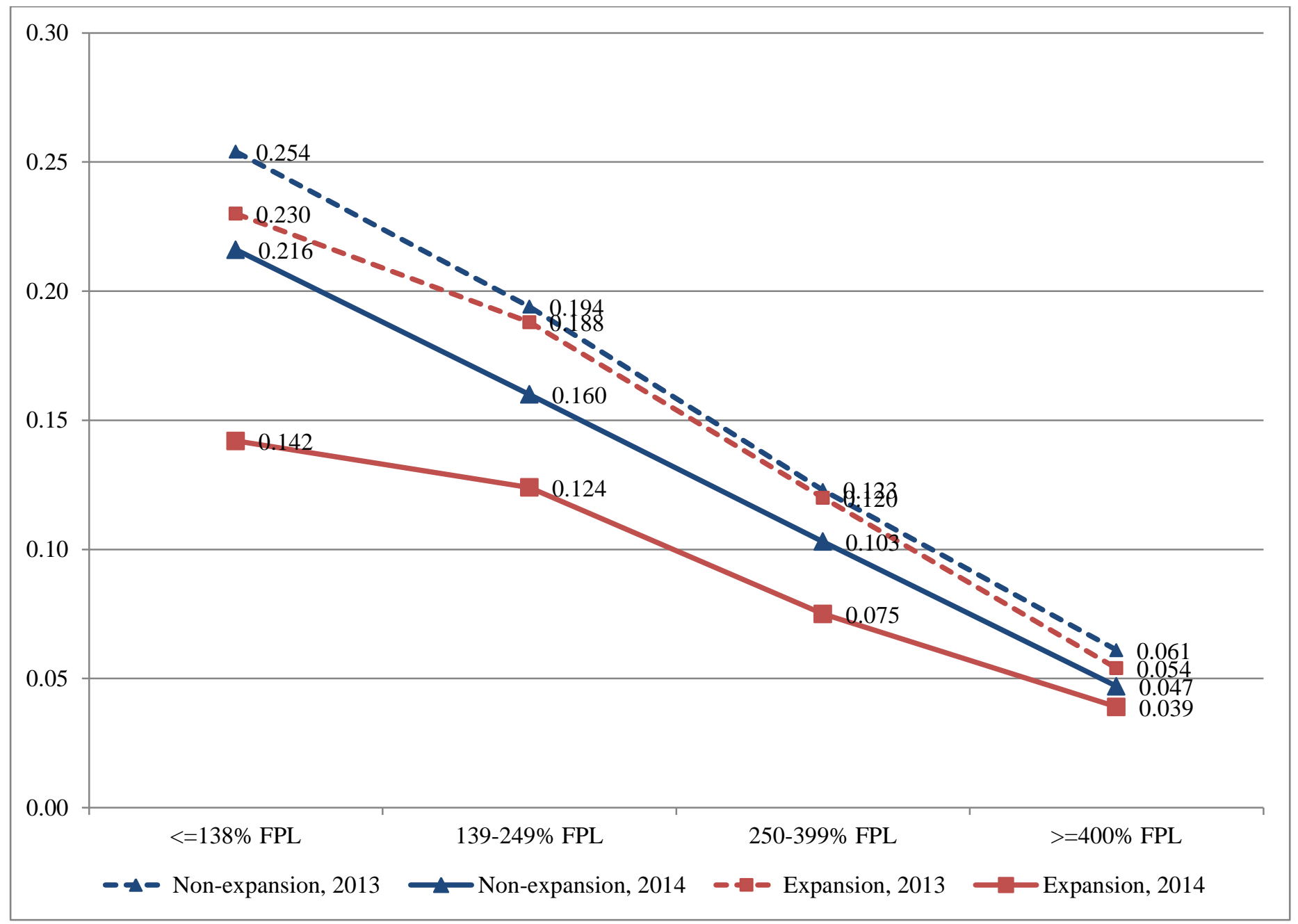

